ワッハーブ派の政治理念と国家原理

一宣教国家サウディアラビアの成立と変質一

\title{
Wahhabi's Political Ideas and Principles of the State
}

- Foundation and Transformation of Missionary

State Saudi Arabia -

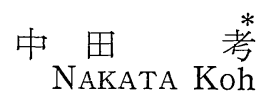

ABSTRACT Ibn 'Abd al-Wahhāb who started his Tawhìd propagation in his hometown, 'Uyaina, in 1741, broke down tombs of saints, trees and stones worshiped by the inhabitants, and pressed the magistrate to carry out the Islamic execution on an adulteress. The frightened inhabitants expelled him from the town.

In this first stage of his missionary activity, we can already find the three political ideas of Wahhabī, such as (1) propagation of Tawhìd, (2)ordering what is right and prohibiting what is wrong, and (3) execution of the Islamic law.

Expelled from his hometown, Ibn 'Abd al-Wahhāb came to Dar' ìya where lived Ibn Sa'ūd. Ibn Sa'ūd visited him and proposed him a concordat according to which he would give Ibn 'Abd al-Wahhāb a military support for the propagation of Tawhìd in exchange for his loyalty to the house of Sa' $\bar{u} d$ and his confirmation of Ibn Sa'ūd' s right of taxation. Ibn 'Abd al-Wahhāb accepted his proposition except the confirmation of the right of taxation. On this concordat are founded the three State Principles of Saudi Arabia: propagation by $j i h \bar{a} d$, monarchy of the Sa'ùd, and no taxation.

With the expansion of the territory, Saudi Arabia starts to use a double identity in the foreign policy, in which they define themselves as Wahhābi to attack the non-Wahhābì Muslims as polytheists on one hand and as Hanbali to make peace with other Muslims on the other

* 山口大学教育学部助教授

Associate Professor, Faculty of Education, Yamaguchi University 
hand.

Though the third kingdom of Saudi Arabia founded by 'Abd al = 'Azīz has inherited Wahhābī' $s$ three ideas on the politics, as for its three principles of the state, it comes to discard jih $\bar{a} d$ as well as to retouch the no taxation principle and to justify the diplomatic relation with non Muslim countries.

The legitimacy of the third kingdom of Saudi Arabia is now threatened on the three levels, namely, (1) the penetration of the idea of of the Jihād-Revolution among people, (2) the intensifying conflict not only between the Western world and the Islamic world but also between secularism and Islamism within the Islamic world and (3) the heavy taxation under the circumstances of the financial decline.

序

現在のサウディアラビア王国は，第 3 次サウディアラビア王国（以下，第 3 次王国と略す）とも呼ばれる。それは第３次王国が，ムハンマド・ブン・サウ ード（以下，イブン・サウードと略す）とムハンマド・ブン・アブド・アルー ワッハーブ（以下，イブン・アブド・アルーワッハーブと略す）の「政教盟約」 によって成立したサウード家の率いる「宣教集団」第 1 次サウディアラビア王 国（以下，第1次王国と略す）の「正統」な後継者であると自ら認じ，またそ のように他者からも認知されているからである。

イブン・サウードの族長支配と現在の中央集権官僚国家たるサウディアラビ ア王国とを一括して「国家」と呼ぶことは，政治学的にはナンセンスであろう。 にもかかわらずワッハーブ派の自己理解に抢いては両者の連続性が自明とされ ていることもまた事実である。

全ての「国史」が「神話」であるのと同様に「サウディアラビア史」るまた 「神話」にほかならない。しかし同じく神話でありながらも，神話が現代を規 定する力はそれぞれの神話によって異なる。例えば現代日本史学の「日本史」 はもはやかつての「皇国史観」がそらであったほどには日本の現在と未来を規 定するものではないが，第 1 次王国の「建国史」は規節的歴史として今日の第 3 次王国の在り方をも強く拘束している。言い換えれば初期イスラーム史がウ ソマにとって超歴史的な規範的歴史としてイスラームの政治理念の基礎となっ 
ているように，サウディアラビアに预いては，第 1 次王国の「建国史」それ自 体がワッハーブ派の政治・国家理念の構成要素の一つとなっているのである。

本稿ではサウディアラビアの「建国史」の分析によってサウディアラビアの ワッハーブ派宣教国家としての基本的特質を定式化したら劣で，第 3 次王国に 扣ける継続性と変質を明らかにし，最後に現王政の正当性の危機を指摘する。

\section{I. 第 1 次王国の建国}

イブン・アブド・アルーワッハーブは政治については緾まった著述を残して いない。そこで我々は第 1 次王国建国の「正史」とも言兄る『ナジドの歴史』 をワッハーブ派の政治・国家理念を知るための一次資料として利用する。『ナ ジドの歴史』の記するところの第 1 次王国の建国史は以下のように要約するこ とができょう。

イブン・アブド・アルーワッハーブは1703年アラビア半島中部カスィーム地 方のウヤイナの町にハンバリー派の学者の家系に生まれた。イブン・アブド・ アルーワッハーブはバスラ, マディーナなどに留学してイスラーム諸学を修め たのち故郷ウヤイナに戻り，タウヒード（唯一神崇扯）の宣教を始める。善を 命じ悪を禁ずることを使命と心得るイブン・アブド・アルーワッハーブは信ず るところをロで唱劣るだけに止まらず，自ら率先して聖者の廟を破壞し，聖木 を伐採した。

タウヒードに反しシルク（多神崇拝）に通じる「迷信」と戦ら一方で，イブ ン・アブド・アルーワッハーブは, ウヤイナの代官にイスラーム刑法の施行を 命じた。しかしイブン・アブド・アルーワッハーブが姦通を犯した女性に碩殺 刑の判決を下し代官が処刑を執行したことが，反対者たちの間に恐慌を引き起 こし, 彼らの訴光によってイブン・アブド・アルーワッハーブは故郷ウヤイナ を追放される。

1744年イブン・アブド・アルーワッハーブはダルイーヤの町（現在はリヤド 市の一部）に到着した。彼の壿を聞いた同地の豪族イブン・サウードは，イブ ン・アブド・アルーワッハーブの宿を訪ねた。イブン・アブド・アルーワッハ ーブはイブン・サウードに，アッラーフの使徒ムハマンドとその直弟子たちの 宣教の生涯と，アッラーフがそれに報いて彼等に授けた栄光について説き，つ いで当時のナジドの住民のアッラーフの教兄と使徒のスンナ（言行）に背くシ 
ルク, ビドア (教義, 義礼の改変, 丕曲), 分裂, 不正の現状を語った。以上 のような話を聞いたイブン・サウードは言った。

「師よ，まさしくそれこそ疑念の余地のないアッラーフとその使徒の御 教光です。拈喜び下さい。私は貴方とその命を奉じ, タウヒードに背く者

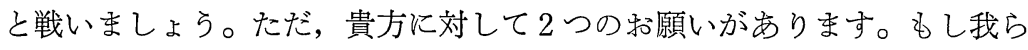
が貴方を助け，アッラーフの道弾い，アッラーフが我らと貴方に諸国を 征服させ給らた時，私は貴方が我々を捨てて，他の者をして我々に替兄ら れるのではないかと恐机ます。

2つ目（の願い）といらのは，私には現在ダルイーヤ地方の住民から 果実收穫時に徵収している租税収入（qānūn）があるのですが，貴方が住 民からは何も取ってはならないと私に命じるのではないかと心配していま す。」

\section{そこでイブン・アブド・アルーワッハーブ師は答光た。}

「第1の願いに関しては，貴方の手を差し出さない。貴方の血は私の血， 貴方の死は私の死としょう。第 2 の願いについては，扔そらくアッラーフ が貴方に征服地を与光，（現在得ている）租税（収入）以上の戦利品によ って償って下さらう。」

ここにイブン・サウードは手を差し出し，イブン・アブド・アルーワッ ハーブに，アッラーフとその使徒の教光を守り，アッラーフの道でのジ八 一ドを行い,イスラームの法を施行し，「善の命令と悪の禁止」を行う誓 いを立てた。

こらしてイブン・アブド・アルーワッハーブとイブン・サウードの間に政教 盟約が成立し，以後イブン・アブド・アルーワッハーブはイブン・サウードの 武力を背景にタウヒードの宣教を推し進めていくことになった。

イブン・アブド・アルーワッハーブの唱光るタウヒードの宣教は, 行く先及 で敵対，迫害を被ることになった。しかしイブン・アブド・アルーワッハーブ の予言通り, 宣教の敵とのジハードの過程で巨額の戦利品を蓄兄, ダルイーヤ の小豪族に過ぎなかったサウード家は，ナジドの霸者となるにいたり，大サウ ード(イブン・サウードの孫, 在位1803-14年) の時代には東部州はアフサーゥ, カティーフからカタルまで, 西はヒジャーズの地方全域, 北はアラビア半島を 越光てシリア，イラクの一部，南はアスィール，ナジュラーンからイエメンと 
オマーンの一部を支配下に括き，アラビア湾から紅海に至るサウード家最大の 版図を実現したのである。

\section{II. ワッハーブ派宣教国家の成立}

前節ではサウディアラビアの建国の歴史を概観したが，本節ではウヤイナ時 代のイブン・アブド・アルゥワッハーブの宣教活動からワッハーブ派の政治理 念を, 政教盟約から第 1 次王国の国家原理を析出し，イブン・アブド・アルー ワッハーブによるマッカへの名代の派遣の記録を手掛かりにワッハーブ派のア イデンティティー構造を明らかにする。

\section{(1) 政治理念}

我々はイブン・サウードの知遇を得る以前のウヤイナ時代のイブン・アブド ・アルーワッハーブの活動の中に既に，後のワッハーブ派の宣教の方向性を見 て取ることができる。それは先ず(1)タウヒードの宣教であり，次いで(2)「善の 命令と悪の禁止」の実践, そして(3)イスラーム法の厳格な施行, とまとめるこ とができよう。

イブン・アブド・アルーワッハーブの主著が端的に『タウヒードの書』と名 付けられていることに象徵されるように，タウヒード概念こそ，彼の宣教の本 質を成す。イブン・アブド・アルーワッハーブは真のイスラームとはタウヒー ドの実践，つまりシルクの峻拒にあるとし，それを犯すことによってムスリム がイスラーム共同体から「破門 (mukhrij al-milla)」されるシルクの形態の 解明に学的努力を傾注した。

彼の目の映った当時の「ムスリム」は，聖者に祈願を行い，最後の審判の日 の執り成しを祈り，聖者廟に参扯し，また霊験あらたかな聖木を祠るといった 宗教生活を送っていたが，それはタウヒードの否定であり「破門」に值するシ ルクに他ならなかった。それゆ穴イブン・アブド・アルーワッハーブは自ら率 先して聖者の廟を破壊し，聖木を伐採したが，それは「善の命令と悪の禁止」 の実践を意味した。「善の命令と悪の禁止」の実践は力に応じた義務であるた め，イブン・アブド・アルーワッハーブが公権力に影響力を及洔すことができ るようになった時点でさらに強化され，姦通を犯した女性に法定刑を施行され るに至ったと解釈できる。

(1)タウヒードの宣教, (2)「善の命令之悪の禁止」の実践, (3)イスラーム法の 
厳格な施行は，イブン・サウードとの盟約の成立以前に湖るワッハーブ派の宣 教の本質であるが，この三者は決して同格ではない。つまりイブン・アブド・ アルーワッハーブにとってはタウヒードはシルクと二項対立的に把握されて抒 り，従って(1)タウヒードの宣教がイスラームの宣教と同一視される絶対的な至 上目的であるのに対し, (2)「善の命令と悪の禁止」の実践, (3)イスラーム法の 厳格な施行，は公権力と結び付くことを前提として初めて顕在化する相対的な 要請なのである。この意味でタウヒードの宣教が「政治」に方向性を与えるも のでありながらも政治を越えた絶対的な信条であるのに対し，「善の命令と毌 の禁止」の実践，イスラーム法の厳格な施行こそ狭義の政治理念と言らことが できよう。だが本稿では便宜上三者をまとめてワッハーブ派の政治理念と呼ぶ ことにする。

\section{(2) 国家原理}

イブン・アブド・アルーワッハーブの宣教は当初より，「善の命令と悪の禁 止」の実践，イスラーム法の厳格な施行，といら政治的志向性を有したが，イ ブン・サウードとの盟約の成立により，新たな次元が加わることになる。それ は「国家原理」とでも呼ぶべきものである。イブン・アブド・アルーワッハー ブとイブン・サウードの政教盟約には(1)ジハード（聖戦）による宣教，(2)サウ ード家の王政の承認, (3)無課税財政の3つの国家原理が集約されている。ここ で注目すべきなのは，建国の伝承に既にサウディアラビアの和ける王家と宗教 界の間の緊張関係が示唆されている点である。

イブン・アブド・アルーワッハーブにとっては, タウヒードの宣教, 即ち彼 の理念の実現こそ全てであったのに対し，イブン・サウードにとっては宣教の 援助々一族の現世に和ける繁栄は不可分であった。そこでイブン・サウードは

『ナジドの歴史』に記されているよらにイブン・アブド・アルーワッハーブの 宣教の援助を約するにあたり, 宗教界のサウード王家への恒久的な支持と徵税 権の追認を要求するが，彼はサウード王家への恒久的支持については承認する が，徵税権の要求は拒否する。なぜならシャリーアの定める国家の財源は，イ スラーム教徒の納める法的喜捨 (zakā), 異教徒の納める貢租, 異教徒との戦 いによる戦利品のみであり，信徒から庇護を名目に法定喜捨以外の税を取るこ とは認められていないからである。イブン・アブド・アルーワッハーブはイブ ン・サウードに徵税を禁ずる代わりにそれ以上の戦利品収入を約束し，イブン 
・サウードはこれを承認し徵税権の追認の要求を取下げ，ここに政教盟約が成 立する。

宗教界とサウード王家の同盟は，当初より王家の現世での繁栄を条件とする ものであった。そして征服地から安定した徴税を禁じられた王家にとって，富 の獲得, 戦士団への分配の手段は戦利品の獲得しかなかった。言い換光れば宣 教国家サウディ・アラビアは教義的にジハードによる宣教を正当化するのみな らず，存続のために構造的に不断のジハードを要請する軍事拡張主義国家でる あったのである。

\section{（3）二重アイデンティティー構造}

ジハードはイスラーム法上「不信仰者との戦い」とされる。従ってジハード が宣戦されるためには，予め敵のタクフィール（不信仰者であるとの判定）が 必要となる。ところが既述のようにイブン・アブド・アルーワッハーブは，タ ウヒードとシルクを二項対立的に把握して和り, 従って『ナジドの歴史』がワ ッハーブ派を端的に「ムスリム」，ワッハーブへ派の服従を「イスラームへの 入信 (al-dukhūl fī al-islām)」, 離反を「背教 (irtidād)」と記しているように タウヒードを実現する者, 即ち彼の教えに従ら者のみがムスリムであり，彼の 教えに背く者はムシュリク (多神教徒)，不信仰者とされるのである。

にも拘わらず，ワッハーブ派のタクフィールは当初より瞹昧さを残して招り， 決して厳格に適用されてはいない。『ナジドの歴史』は, ワッハーブ派のアイ デンティティーの 2 重性を象徴する興味深いェピソードを記している。

1771/2年, マッカの太守アルーシャリーフ・アフマドからの要請に応じて， イブン・サウードとイブン・アブド・アルーワッハーブはワッハーブ派の教義 を説明するために，アブド・アルーアズィーズ・アルーフサインを 2 人の名代 として派遣する。

アルーフサインはアフマドに対する 2 人からの書簡を携えていた。その書簡 には「(アルーフサインが）もし彼ら（マッカのウラマーゥ）と意見が対立す るようなら，アフマド殿に和かれましては，彼らの諸書とハンバリー派の諸書 を持ってこられよ」と書いてあった。マッカのウラマーゥたらはワッハーブ派 の教義とハンバリー派の学説とを比較検討した結果, 両者が一致することを確 認した。アルーフサインは彼らの称賛を受けてダルイーヤに名誉ある帰還を果 たしたと言われる。このエピソードはワッハーブ派が当初より，スンナ派正統 
4 学派の 1 つであるハンバリー派として自らを位置づけることによって, 他宗 教との共存を図る論理を用意して和り，また非ワッハーブ派側もハンバリ一派 への帰属を理由にワッハーブ派の存在を許容し得たことを示している。 つまりワッハーブ派は，（1）ワッハーブ派のみをムスリムとみなす「ワッ ハーブ派・アイデンティティー」と，（2）非ワッハーブ派を含む全ての「ム スリム」をムスリムと認めた上で自らをその 1 学派「ハンバリー派」と位置づ ける「ムスリム・アイデンティティー」の二重のアイデンティティーを有する。 この二重アイデンティティーは形式的には同心円構造を有する。但し伝統的な ハンバリー派の二重アイデンティティーの同心円が連続的であるのに対して， ワッハーブ派の同心円の 2 つのは，「我々の時代の多神教徒（非ワッハーブ 派ムスリム）は，アッラーフの使徒の時代の不信仰者（キリスト教徒，ユダヤ 教徒, 偶像崇拝者) よりも深い迷妄に陥っている」とのイブン・アブド・アル ーワッハーブの言葉に明らかなように連続性を有する以上に互いに鋭く対立す る。

つまり伝統的なハンバリー派のアイデンティティーに和いては，非ハンバリ 一派のムスリムは，イスラーム共同体内部では他学派として対立しても，キリ スト教徒などの異教徒に対しては同じ「ムスリム」として括りらるるのである のに対し，ワッハーブ派のアイデンティティーに拈いては非ワッハーブ派「ム スリム」は，「多神教徒」であり, 非ムスリムのキリスト教徒やユダヤ教徒以 上に敵視すべき存在なのである。

\section{III. 第 3 次王国における宣教国家の変質}

1992年，ファハド国王は実質的には憲法にあたる統治基本規則を発表する。 同規則発布にあたっての演説の中で，ファハド国王は「ムハンマド・ブン・ サウード公 (imām) とムハンマド・イブン・アブド・アルーワッハーブ師 (shaykh) といら 2 人の公正な改革者（muṣlih）がイスラームに基づく盟約を 結んだことによって，イスラームを基礎として第 1 次サウディアラビア王国が 成立した」と述べ，第 3 次王国の支配の正当性をイブン・アブド・アルーワッ ヘーブとイブン・サウードの政教盟約に基礎づけだ

また統治基本規則第 23 条「国家はイスラームの信条を護り，そのシャリーア を適用し，善を命じ悪を禁じアアッラーフの宣教の義務を果たす。」には(1)夕 
ウヒードの宣教，(2)善の命令と悪の禁止の実践，(3)イスラーム法の厳格な適用， というワッハーブの政治理念が凝縮されている。

ところが(1)ジハードによる宣教，(2)サウード家の王政，(3)無課税財政とのワ ッハーブ派の 3 つの国家原理について言觉ば，第 5 条が王位が第 3 次王国の建 国者アブド・アルーアズィーズ王の直系男系卑属に属することを明文化し，サ ウード家の王政の原理を確認している一方で，無課税財政の原理については第 20 条に「必要性と正当性がある場合以外は租税公課が課されることはない」と 瞹昧な立場をとって拈り，またジハードについては全く言及がない。

既述のように無課税の原則はジハードによる戦利品収入を前提として始めて 成り立つものであった。第 3 次王国の建国者アブド・アルーアズィーズは1920 年代に入るまでは法定喜捨（zakāt） と戦利品五分の一税 (khums) のみを課 す無課税の原則を貫いていた。しかし第 1 次大戦後，イギリスの圧力により自 由にジハードを行らことはできなくなり，1920年代初頭にはアブド・アルーア ズィーズは物品税を導入する。ナジドのウラマーゥは物品税の課税がイスラー ム法上非合法とのファトワー（法判断）を発し，課税問題はイフワーンの反乱 の主要原因の一つとなった。またアブド・アルーアズィーズは1950年に所得税 (darība al-dakhl) 法を導入したが，翌1951年にはこの所得税がシャリーアに 反するとの抗議により同法は改正された。

ジハードの停止はジハードによる宣教を不可能とするばかりでなく戦利品の 停止を意味し無課税の原則をも危うくした。しかしジハードを停止したとして もタウヒードの宣教自体はワッハーブ派の至上目的であり放棄することは不可 能である。アブド・アルーアズィーズは平和的手段による宣教を継続して䄮り， 彼は巡礼の場を通じて海外からの巡礼にワッハーブ派の理念の宣揚に努めると (23) 同時に，イスラーム世界全域への配布のために約10万冊のワッハーブ派の基礎 文献を出版している。

またアブド・アルーアズィーズはワッハーブ派の宣教と軌を一にするサラフ ィー主義のラシード・リダーの『マナール』誌への援助を行い, 同誌の出版局 の印刷, 出版のためにサウディ政府予算を割いた。「『マナール』は『アラブ世 界に括けるイスラーム改革の最も重要な声であった』し，『モロッコからジャ ワにいたる広汎な配布によってイスラーム世界全体に影響を与えたのである』」 と言われる『マナール』の影響力を考劣るとき，アブド・アルーアズィーズの 
『マナール』支援はワッハーブ派の対外宣教に大いに貢献したと言えよう。

また無課税の原則については，1930年代以降の石油の発見以降，戦利品収入 に代わって安定した石油収入を得て，様々な名目の関税，物品税は導入された ものの，所得税の導入は見送られ，無課税の原則はまがりなりにも維持された のである。

ジハードはイスラーム法上の義務である以上，非ワッハーブ派を多神教徒と みなしタウヒードの宣教を至上目的とするワッハーブ派にとってジハードの停 止は重大な神学的意味を有する。既に見たようにワッハーブ派は, 二重アイデ ンティティーの使い分けによって非ワッハーブ派ムスリムとの共存を可能にし ていた。しかし第 3 次王国は外国人異教徒との友好関係の樹立といら新たな問 題に直面していた。

アブド・アルーアズィーズのイギリスとの同盟はイフワーンから「アブド・ アルーアズィーズはイギリスに身売りをした」との批判を招き，イフワーンの 反乱の一因となった。アブド・アルーアズィーズの時代，ワッハーブ派は非ワ ッハーブ派「ムスリム」によって 2 度にわたり国を滅ぼされ，信徒住民を虐殺 される苦い体験を積んでいた。そこでアブド・アルーアズィーズは，「私の外 国人への警戒が 1 であるとすればイスラームを称する者への警戒はその 3000 倍 である……」，「部のムスリムはイスラームとムスリムの名によってナジドの 民に陰謀を仕掛け，何世代にもわたってイスラームの名を騙ってムスリム同胞 と戦っているのである」と述べ，非ワッハーブ派「ムスリム多神教徒」を主要 敵とするワッハーブ派の宣教理念に亡国の歴史を重ね合わせ，主要敵が異教徒 ではなく非ワッハーブ派「ムスリム多神教徒」であることを改めて確認するレ トリックを用いることにより, 異教徒との和平の「非問題」化をはかった。言 い換光れば，亡国の歴史を投影することによって，イスラーム世界内でのジハ ードを優先するワッハーブ派の世界観を強化することによって「異教徒」とム スリムの二項対立の相対化をはかったのである。

しかし一方でイスラームの聖地マッカ，マディーナを含むヒジャーズの併合 後, 第 3 次王国は非「ワッハーブ」派「ムスリム」諸国との恒久的な関係を取 り結ぶことを強いられ，そこではサウディアラビアはワッハーブ派アイデンテ ィティーを押さえムスリム・アイデンティティーを前面に掲げることになる。 そこで第 3 次王国は対内的には「ムスリム・アイデンティティー」を揭げてイ 
スラーム世界内外交を，「ワッハーブ派アイデンティティー」の強調により非 イスラーム世界外交を対内的に正当化することになった。

二重アイデンティティーの使い分けによる外交問題の処理は第 1 次王国に掠 いても存在したが，第 1 次王国では視野の外にあった欧米との外交関係の樹立 が第 3 次王国では現実的に主題化することによって, 二重アイデンティティー の使い分けの必要が増すと同時に，2つのアイデンティティーの間の矛盾の処 理は一層困難になったと言うことができよう。

\section{IV. 正当性の危機の現在}

(1)タウヒードの宣教, (2)「善の命令と悪の禁止」の実践, (3)イスラーム法の 厳格な適用といらワッハーブの政治理念とサウード家による王政との国家原理 を第 1 次王国から継承しつつも, ジハードによる宣教を放棄し, 無課税財政の 原則を崩した，といら点に括いて第 3 次王国は「修正ワッハーブ派」宣教国家 と呼ぶことができよう。

第 3 次王国は, 第 2 次世界大戦後の国際秩序の中で西側陣営に組み込まれた ことにより，ますます西欧との関係を深め，相対的にムスリム・アイデンティ ティーとワッハーブ派アイデンティティーの二重アイデンティティーを共に弱 めつつも，いまな执欧米の世俗主義の政教分離を拒否し，アブド・アルーアズ ィーズが基礎を築いた修正ワッハーブ派宣教国家であり続けて現在に至ってい る。

第 3 次王国は，1929年のイフワーンの反乱と1979年のマッカ事件の 2 度にわ たる宗教勢力による反乱を乗り切ったが，イデオロギー・レベルに执いては現 在，より深刻な支配の正当性の危機を迎えつつあるように思われる。そこで第 3 次王国が現在直面している正当性の危機の要因を分析的に（1）理論的要因, （2）国際的要因，（3）社会的要因，に区別し以下にまとめ，本稿の結びとし たい。

\section{(1) 理論的要因}

第 3 次王国の法制の実態が欧米実定法であり，法制に和ける実定法の施行が シルク（多神教徒）に当たるとの認識が浸透しつつある。この認識は前王国最 高ムフティー（法官）ムハンマド・ブン・イブラーヒーム・アール・アルーシ ヤイフ（d. 1970）によって定式化されていたが，現在のワッハーブ派反体制派 
は聖跡崇帱と実定法の施行を等置するまでに至っている。聖跡崇拝は既述のよ らにワッハーブ派のタウヒードの宣教の主要敵であり, ワッハーブ派はタウヒ 一ドの宣教を至上目的とし元来強いタクフィール志向を有する。実定法を施行 する体制のタクフィール，ジハードによる打倒を説く「革命のジハード論」が イスラーム世界で急速に広まりつつある現在，同じタクフィールの志向性を有 するワッハーブ派の内部での実定法の志向が聖跡崇择と同じシルクであるとの 認識の浸透は極めて重大な意味を持つのである。

(2) 国際的要因

第 2 次世界大戦後の冷戦構造の終結の中で, 経済的, 政治的に世界のボーダ レス化が進む一方で，議論を呼んだ、ムエル・ハンティントンの「文明の衝 突」(『中央公論』1993年 8 月) に代表されるよらに，イデオロギーのレベルで は西欧（ユダヤ・キリスト教）世界とイスラーム世界の対立が先鋭化するとの 認識が双方で深まりつつあり，第 3 次王国に括いては非イスラーム諸国との友 好外交の宗教的文脈での正当化が困難になりつつある。

またイスラーム世界内外交をとっても，冷戦構造終結以降イスラーム世界内 で顕在化した反世俗主義運動の主たる担い手がワッハーブ派と類縁関係にある サラフィー主義者であり，世俗主義政府と反体制派が現実の戦闘状態に入った 現在，ムスリム・アイデンティティーとワッハーブ派・アイデンティティーの 緊張はますます高まり，二重アイデンティティーの使い分けによるイスラーム 世界内外交の国内的正当化は不可能となりつつある。

(3) 社会的要因

最後に社会的要因としてはサウディ経済の悪化があげられる。課税の合法性 を巡る議論はアブド・アルーアズィース以来燻り続けているが，湾岸戦争後， イスラーム法に反する立法が不信仰にあたることを前提とした上で，国税が非 合法であるとの批判が高まっている。

西洋史上も課税問題が発端となり「代表なくして課税なし」の原則を揭げて アメリカ独立革命が起きた経緯があるが，元来無課税を国家理念として明確に 規定しているワッハーブ派国家に特いて経済の悪化により重税感が高まれば, 課税問題が政治の焦点化し，ひいてはサウード王家の「非民主的」支配への批 判が顕在化することも考学うるのである。 


\section{注}

（1）サウディアラビアにはワッハーブ派以外にもスンナ派伝統主義者やシーア派など 少数派が存在するが，本稿ではこれらの少数派については扱わない。

（2）『ナジドの歴史』の著者フサイン・ブン・ガンナーム（d. 1810/1）は東部州の町 アフサーゥの出身。イブン・アブド・アルーワッハーブの弟子でアフサーゥのムフテ ィーを務め，彼の命により『ナジドの歴史』を著した。cf., Aḥmad Bakir Mahūmd, Ishām fī Tãrīkh al-Madhhab al-Hanbalī, Beirut-Damascus, 1990, p. 108.

(3) Ḥusayn bn Ghannām, Tärīkh Najd, Riyadh, 1403, pp. 78-80.

（4）Ghannām op. cit.,pp. 80-81.なお qānūn とはナジドの方言で，弱者が庇護の見 返りに果実の収穫時に強者に払ら用心棒代を指す。ibid., p. 81 .

また別伝には「‥貴方は一族の長であり尊貴な方である。貴方に誓っていただきたい 一この宗教のために戦らこと，そして首長職とイマーム権は貴方と貴方の子孫に属し， 宗教に打けるシャイフ職と（預言者の）代理権は私と私の子孫に属すること，われわ れが同意しないかぎり，いかなる決定も講和も戦争もなされないことを。」(小杉泰， 『現代中東とイスラーム政治』，昭和堂，1994年，271頁参照。と）述べたとあるが， 現代サウディアラビアの歴史学者の中には，この伝承の信憑性を疑ら者もある。cf., 'Abd Allāh al-Ṣāliḥ al-'Uthaymin, Tārīkh al-Mamlaka al-'Arabīya al-Sa'ūdìya al-'代 $\bar{a}$, vol. 1, p. 86.

(5) cf., ibid., pp. 149-150.

(6) cf., Muḥammad bn 'Abd al-Wahhāb, Kitāb al-Tawhīd (with Kitāb alQawl al-Sadìd), Riyadh, 1982.

(7) cf., Ghannām, op. cit., pp. 10-19.

（8）中田考, 湯川武, 『イスラーム政治論一ーイブン・タイミーヤ シャリーアによ る統治』，日本サウディアラビア協会，1991，53-54頁。

なお徵税の問題については後述。

（9）アルーウサイミーンも次のように述べている。

「第 1 次サウディ・アラビア国の最も重要な特徵に, 1740年から1818年の隇亡にい たるまで，敵との間に戦い（ghazwa）のなかった年が 1 年たりともなかったという ことがある。それらの戦いには防衛的性格のものもあったが，殆どは攻勢であった。

おとらく徵兵された者の中には，信仰心によって戦闘への参加を求めて馳参じた志 願兵がいたと共に, 戦利品の分前に与かることを望んで参加した志願兵もいただろう。 というのもこのサウディアラビアの戦争は殆どが勝利であったからである。」cf., al'Uthaymin, op. cit., p. 186.

（10）アルーフサインは $1741 / 2$ 年生まれ。イブン・アブド・アルーワッハーブの高弟の

1 人であり，ワシュムの裁判官を勤め，1771/2 年と $1789 / 90$ 年の 2 回にわたりイブン

・アブド・アルーワッハーブの名代としてマッカに派遣された。1822年没。 cf., al- 
'Uthaymin, op. cit., p. 183, 'Uthmān bn Bishr al-Najdi al-Hanbalī, 'Unwān alMajd, Riyadh, n. d., vol. 1, p. 234.

(11) cf., Ghannām, op. cit., pp.131-1337 イブン・アブド・アルーワッハーブ自身 も「また我々は法学各論に拈いてはハンバリー派 (madhhab al-Imām Aḥmad bn Hanbal) に属する」と述べている。cf., Aḥmad al-Qațțān, Muḥammad al-Zayn, Imām al-Tawhìd al-Shaykh Muhammad bn 'Abd al-Wahhāb, Kuwayt, 1986, p. 139.

また ‘Abd al-Qādir bn Badrān al-Dimashqi al-Madhal ilä Madhhab al-Imām Ahmad bn Hanbal, Beirut, 1981, 'Abd Allāh bn 'Alī bn Humayd alSubay'ì al-Makkì al-Ḥanbalī, al-Durr al-Munaḍ̣ad fī Asmā’ Kutub Madhhab al-Imām Aḥmad, Beirut, 1990, Sālim 'Alì al-Thaqafi, Mafātīh al-Fiqh al-Hanbalì, Makka, 1978, Aḥmad Bakīr Maḥmūd, Ishām fī Tārīkh al-Madhhab al-Hanbalī, Beirut-Damascus, 1990, などのハンバリー派法学に関する学術書はいずれもワッハ ブ派のイスラーム学者をハンバリー派に分類している。

(12) Muḥammad bn 'Abd al-Wahhāb, Majmū'a Mu'allafāt al-Shaykh al-Imām Muhammad bn 'Abd al-Wahhāb, n. p., n. d., vol. 5, p. 125.

(13) 'Īd Mas'ūd al-Juhanī, al-Shūrā wa Fann al-Hukm fī al-Mamlaka al-'Arabìya al-Sa'üdìya, n. p., n. d., pp. 423-424.

（14）ibid., p. 442. また統治基本規則前文があげるサウディアラビアの 9 つの基礎 (rakiza) の第 1 はタウヒードの信条, 第 2 がシャリーア, 第 3 がイスラームの宣教, 第 4 が善の命令と悪の禁止である。cf., ibid., p. 425-426.

（15）ワッハーブ派の 3 つの政治理念のらち，「善の命令と悪の禁止」についてはアブ ド・アルーアズィーズは1926年にとれを初めて職制化し, ウマル・アール・アルーシ ヤイフを「善の命令と悪の禁止機関」長官に任命した。cf., Ibrāhím bn 'Uwayḍ al -Tha 'labì al-'Utaybì, Tanzīmāt al-Dawla fī 'Ahd al-Malik 'Abd al-'Azīz, Riyadh, 1993, pp. 278-279. シャリーアの厳格な適用に関しては, アブド・アルーア ズィーズの治世には殺人罪には同害報復刑が適用され，铂盗犯は手首を切断されるな ぞ，刑法，民法，商法など全ての領域でイスラーム法の規定が迅速に適用されていた と言われる。cf. Subḥi al-Maḥmasānì, al-Awd̄ă al-Tashrī‘iya fī al-Duwal al'Arabìya Mädì-ha wā Hādir-hä, Beirut, 1981, p. 407.

アブド・アルーアズィーズのタウレードの宣教について後述する。

(16) cf., al-Juhanī, op. cit., p. 437.

(17) cf., ibid., p. 441.

(18) cf., Kostiner, Joseph, The Making of Saudi Arabia 1916-1936, Oxford, 1993, p. 41.

（19） cf., ibid., p.81. イギリスはイブン・サウードにワッハーブ派部族民による国境 侵犯の「略奪」を押さえさせるために補助金を与爫る政策を取った。cf., ibid., pp. 
61，81-82，111. この補助金がイブン・サウードの「国家」にとって戦利品収入の代 わりを果たしたのである。

（20）1927年 2 月17日，15名のナジドのウラマーゥが課税を非合法とするファトワーを 発し，イブン・サウードはその撤回を求めたが成功しなかった。cf., ibid., pp. 114$116,118$.

（21）イフワーンの要求には課税の撤回の他に, 電報の撤去, イラク, クゥェイトヘの 侵攻の許可などがあった。イブン・サウードは課税以外の問題では概ねウラマーゥの 支持を取り付けることに成功しているが，課税問題は例外でウラマーゥはイフワーン に同調した。またイブン・サウードも課税問題に関しては，部族長への分配金がなく なるとの条件で課税は撤回可能である，とイフワーンに妥協の姿勢を示している。 cf., ibid., pp. 114-116, 118, 126-127, 130-131.

（22）個人所得税は1950年11月 2 日の栜令による $5 \%$ の所得税の課説以前には法制化さ れず，この税法もシャリーアに反するとの反対が強かったため, 翌1951年 4 月 6 日の 勅令で所得税は非サウディアラビア人のみに課され，サウディ人にはザカーだけが課 されるように改正された。cf., al-'Utaybi, op. cit., p. 362.

（23）巡礼はワッハーブ派の宣教の重要な場であり，19世紀にかけてワッハーブ派の宣 教はマッカ巡礼を通じてアラブ世界を越えてインド亜大陸, インドネシア，ブラック アフリカにも広がっていた。cf., al-Salmān, op. cit., pp. 84-90, 98-99.

(24) cf., 'Abd al-Muhsin bn Sa'd al-Dāwūd, al-Mamlaka al-'Arabìya al-Sa' ūdìya wa Humūm al-Aqallīyät al-Muslima fì al-'Allam, Riyadh, 1992, p. 219. イブン・サウードの出版したイスラーム関係書籍の詳細については, Muhammad al-Iḥaydab, Min Hayā al-Malik 'Abd al-'Azīz, Riyadh, 1979, p. 252-255.

（25）事実, ラシード・リダーは論敵からは「ワッハーブ派」と呼ばれていた。ラシー ド・リダーの改革運動とワッハーブ派に共通する特徵としては, 聖者, 聖跡崇拝など のビドア (異端的慣行), タクリード (法学派への盲目的追従) の批判, イジュテイ ハード(クルアーンとスンナに基づく自由裁量）の行使などが挙げられる。一方ラシ ード・リダーには, タゥヒードとシルクの二項対立的把握及びそれに基づくジハード の発想は希薄であった。ラシード・リダーとアブド・アルーアズィーズの関係につい では, cf., Muhammad bn 'Abd Allāh bn Sulaymān al-Salmān, Rashīd Rị̂a wa Da'wa al-Shaykh Muhammad bn 'Abd al-Wahhāb, Riyadh, 1408 (h), pp. 254-263.

（26）小杉，前掲書，103頁。

（27）第 3 次王国形成期の財源は戦利品と税収に尽くされるものではなかったが，本稿 では宗教的に重要な戦利品と税収に焦点を絞って論じた。

（28）但しジハードはイスラーム法上の義務であるため，恒久的にジハードを放棄する ことはありえず，そのジハードの放棄は戦略的，あるいは便宜主義的に正当化される しかない。それゆ党1946年の時点ですら，アブド・アルーアズィーズは，「私は，私 
自身と我が子らが，アッラーフの道に憼れることを望んでいる。ムスリムは寝床で永 眠することなどあってはならない。但しジハードを意図していたが，結果的にとらな ってしまった場合は別である。と述べ，ジハードの継続の意志を示して当時のジハ 一ドの中断が例外状況であるのと立場を表明しているのである。cf., Muhyi al-Din al-Qābisi, al-Muṣhaf wa al-Saif, Riyadh, n. d, p. 135.

(29) cf., Kostiner, op. cit., p. 113.

(30) cf., al-Qābisi, op. cit., pp. 82, 56.

（31）アブド・アルーアズィーズの英国人顧問フィルビーの1919年の時点での「『イフワ ーン』の語は, ワッハーブ派の内部サークルに加入したベドウィンを指す。残りはハ ンバリー派である」との発言は, 二重アイデンティティーの溗離を表しているとも言 えよう。cf., Kostiner op. cit., pp. 40-41.

（32）イフワーンはアブド・アルーアズィーズの政策変更を要求したが，彼の廃位を 目指したわけではない。cf., ibid., p. 116. またメッカ事件のイデオローグであった ジュハイマーンもイスラーム法学のカリフ (イマーム) 論に則ってハーリド国王の王 (イマーム) 位の欠格を問題にしたのみであり, サウディの現政体自体をタクフィー ルしたのではなく,「革命」のイデオロギーとしては極めて穏健なるのであった。cf. Abū al-Barā' al-Najdì, al-Kawāshif al-Jalìyh fì al-Dawla al-Sa'ūdìya, London, 1994, pp. 258-259.

(33) cf., Muḥammad bn Ibrāhìm bn 'Abd al-Lațif $\overline{\mathrm{A}} \mathrm{l}$ al-Shaykh, Taḥkim alQawānīn, Riyadh, 1411 (h), pp.16-23. 尚, 同書については稿を改めて論じたい。 （34）サファル・アルーハワーリーは前掲の Tahkim al-Qawānin の解説 Sharh Tahkīm al-Qawānīn の中で, 「世俗主義」, 即ち政治に拉けるシルクことタウヒード の最も危険な最御の敵であると述べている。cf., Safar al-Hawālì, Sharh Tahkim al-Qawānīn (カセットテープ), No. 1, Riyadh, n. d..

またアブー・アルーバラーゥは「真のアッラーフへのタウヒードは, ターグート (邪神), 全てのターグートの拒否（kufr） ととの信奉者との絶縁（barā'a）に立脚 する。それはサウディのイスラーム学者たちが絶えずロにしている石や木のターグー トだけでは断じてなく，全てのターグートである。そらしたターグートにはアッラー フの啓示によらない統治といらターグート，実定法のターグートなどが含まれるので ある」と言う。cf. al-Najdi, op. cit., p. 80.

（35）革命のジハード論については拙稿,「ジハード (聖戦) 論再考」,『オリエント』, 1992年，第35巻第 1 号参照。

革命のジハード論の代表的論客ウマル・アブド・アルーラフマーンは1977年にサウ ディアラビアのアルーイマーム・ムハンマド・イスラーム大学宗教基礎学部に教職を 得たが，その説教の影響を恐れたサウディ政府当局により，1980年国外追放となって いる。cf., New Yorker, 1993/4/12, p. 12, 'Umar 'Abd al-Raḥmān, Așnāf alHukkām wa Ahkām-hā, n. p., 1984, p. 5. 
また1989年にはウマルの弟子アブー・イーサールの著書がサウディ国内で出版され ている。'Abd Allāh Abū Īthār, Hidāya al-Ḧ̄à'rīn fī Man Baddala Sharā'i ${ }^{\star}$ al-Din, Riyadh, Makka, 1989.

(36) cf., Mudhakkara al-Nașịha, n. p., 1992, p.34, al-Najdi, op. cit., p. 37. 